\title{
FALL 2013
}

\section{The}

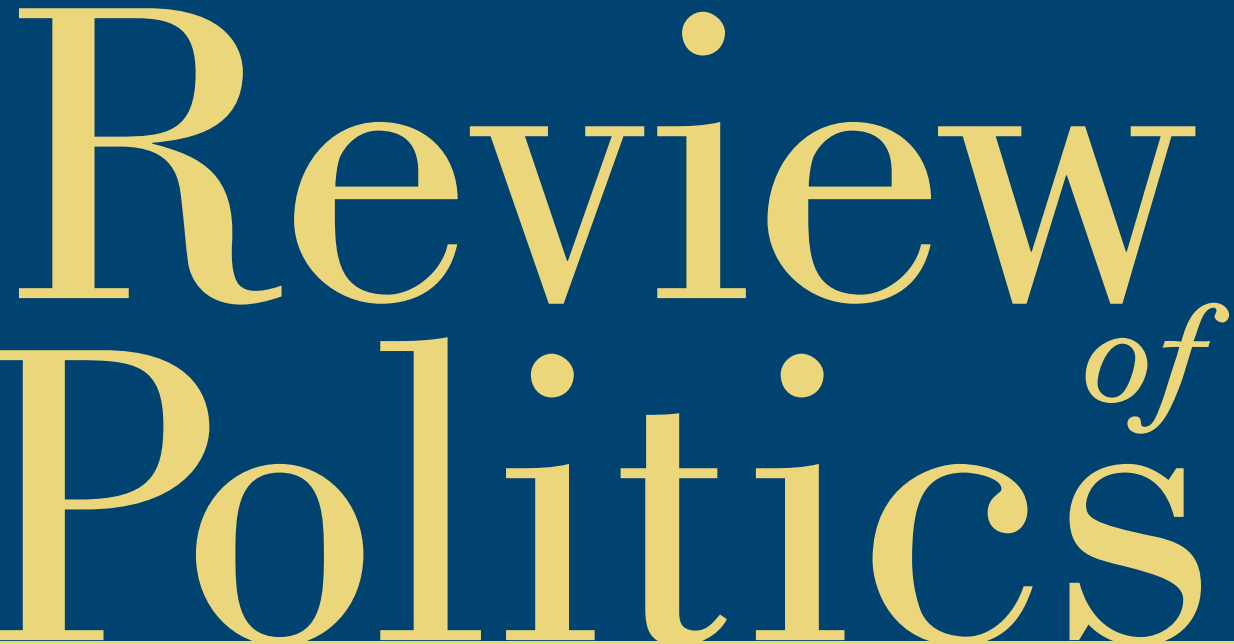

SPECIAL ISSUE: MACHIAVELLI'S PRINCE

William J. Connell, "Dating The Prince: Beginnings and Endings"

Vickie Sullivan, "Alexander the Great as 'Lord of Asia' and

Rome as His Successor in Machiavelli's Prince"

John M. Najemy, "Machiavelli and Cesare Borgia"

Victoria Kahn, "Revisiting Agathocles"

Nathan Tarcov, "Belief and Opinion in Machiavelli's Prince"

Anthony Parel, "Farewell to Fortune"

Miguel Vatter, "Machiavelli and the Republican Conception of Providence"

Giovanni Giorgini, "Five Hundred Years of Italian Scholarship on Machiavelli's Prince"

Harvey C. Mansfield, "Strauss on The Prince" 


\title{
THE REVIEW OF POLITICS
}

\author{
Editor \\ CATHERINE H. ZUCKERT \\ Executive Associate Editor \\ DENNIS WM MORAN \\ Book Review Editor \\ PETER R. MOODY, JR.
}

Editorial Board

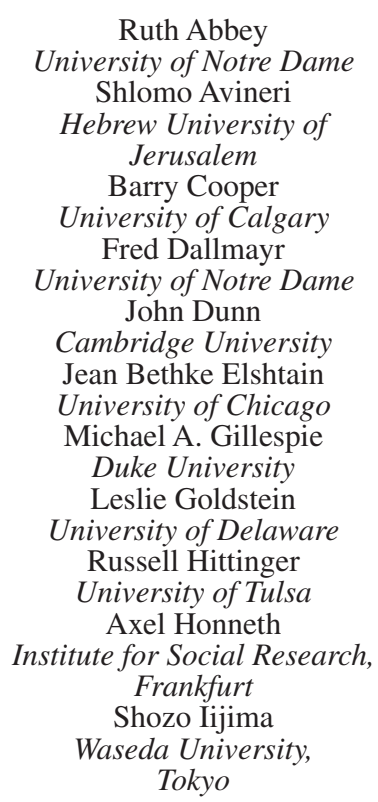

\author{
Ramin Jahanbegloo \\ York University \\ Pierre Manent \\ L'Ecole des Hautes Etudes en \\ sciences sociales \\ Harvey C. Mansfield \\ Harvard University \\ Mary Nichols \\ Baylor University \\ Daniel Philpott \\ University of Notre Dame \\ Arlene Saxonhouse \\ University of Michigan \\ William E. Scheuerman \\ Indiana University, Bloomington \\ Steven B. Smith \\ Yale University \\ Peter Steinberger \\ Reed College \\ Vickie Sullivan \\ Tufts University \\ Jean M. Yarbrough \\ Bowdoin College
}

\section{Copyeditor: LES HARRIS}

Editorial Interns: Nathan Sawatzky, Madeline Cronin Administrative Assistant: Kelli Brown

\section{Former Editors}

\begin{abstract}
Waldemar Gurian
M.A. Fitzsimons

Thomas Stritch
\end{abstract}

\author{
Frederick J. Crosson \\ Donald P. Kommers \\ Walter Nicgorski
}

The Review of Politics publishes primarily philosophical and historical studies of politics, especially those in political theory and American political thought. The journal also includes thoughtful scholarly reflections on all aspects of politics-laws, and institutions, international relations, comparative politics-as well as literary reflections on politics or political interpretations of literature. 


\section{TABLE OF CONTENTS FALL 2013}

Vol. 75

FALL 2013

No. 4

Jean Bethke Elshtain: In Memoriam . . . . . . . . . . . . . . . . . . . . . . 489

Catherine H. Zuckert

Machiavelli's Prince-Five Hundred Years Later . . . . . . . 493

William J. Connell

Dating The Prince: Beginnings and Endings . . . . . . . . . 497

Vickie Sullivan

Alexander the Great as "Lord of Asia" and Rome

as His Successor in Machiavelli's Prince . . . . . . . . . . . . . 515

John M. Najemy

Machiavelli and Cesare Borgia: A Reconsideration

of Chapter 7 of The Prince . . . . . . . . . . . . . . . 539

Victoria Kahn

Revisiting Agathocles . . . . . . . . . . . . . . . . . 557

Nathan Tarcov

Belief and Opinion in Machiavelli's Prince . . . . . . . . . . 573

Anthony Parel

Farewell to Fortune . . . . . . . . . . . . . . . . . . . . . 587

Miguel Vatter

Machiavelli and the Republican Conception of Providence .. 605

Giovanni Giorgini

Five Hundred Years of Italian Scholarship

on Machiavelli's Prince . . . . . . . . . . . . . . . . . 625

Harvey C. Mansfield

Strauss on The Prince . . . . . . . . . . . . . . . . . . . 641

Review Essay:

James P. Sterba

Three Interrelated Views of Punishment . . . . . . . . . . . 667

Reviews:

Albert H. Y. Chen: ASIAN CULTURE AND DEMOCRACY

Review of Doh Chull Shin's Confucianism and Democratization

in East Asia . . . . . . . . . . . . . . . . . . . . . . 673 
Michael Nylan: THE CHINESE TRADITION AND MODERNITY Review of Tongdong Bai's China: The Political Philosophy of the Middle Kingdom . . . . . . . . . . . . . . . . . . . .

Edward S. Krebs: THE ANARCHIST COUNTERCURRENT

Review of John A. Rapp's Daoism and Anarchism: Critiques of State Autonomy in Ancient and Modern China . . . . . . . . . . . . . . . . 680

Svetozar Minkov: PLATONIC RESONANCES

Review of Seth Benardete's The Archaeology of the Soul: Platonic Readings of Ancient Poetry and Philosophy . . . . . . . . . . 682

Jill Frank: BY NATURE AND BY DESIGN

Review of Roslyn Weiss's Philosophers in the Republic: Plato's Two Paradigms . . . . . . . . . . . . . . . . . . . . . . . . . . 685

Kathleen Bossert: THE MAN IN FULL

Review of Travis Curtright's The One Thomas More . . . . . . . . . . 688

Russell Arben Fox: HUMANITÄT

Review of Vicki A. Spencer's Herder's Political Thought:

A Study of Language, Culture, and Community. . . . . . . . . . . . . . 690

Daniel E. Burns: BEYOND RATIONALIST DOGMATISM

Review of Nicholas Tampio's Kantian Courage: Advancing the

Enlightenment in Contemporary Political Theory . . . . . . . . . . . . . 693

Troy E. Smith: ALEXANDER HAMILTON

Review of Michael P. Federici's The Political Philosophy of Alexander Hamilton . . . . . . . . . . . . . . . . . . . . . . . . . . 697

Kevin Walker: CHECKS, BALANCES, AND LIBERTY

Review of Patrick M. Garry's Limited Government and the Bill of Rights. . . . . . . . . . . . . . . . . . . . . . . . 699

Julia Maskivker: THE WISDOM OF CROWDS

Review of Hélène Landemore's Democratic Reason: Politics,

Collective Intelligence, and the Rule of the Many . . . . . . . . . . . . 702

Natalie Fuehrer Taylor: CONTEMPORARY POETS

Review of Paul A. Cantor's The Invisible Hand in Popular

Culture: Liberty vs. Authority in American Film and TV . . . . . . . . 705

Melissa Moschella: LIFEBOAT ETHICS

Review of Tom Koch's Thieves of Virtue: When Bioethics

Stole Medicine. . . . . . . . . . . . . . . . . . . . . . . . 708

Kevin Smant: THE LONG MARCH OF THE NEW PROGRESSIVES

Review of Donald T. Critchlow and W.J. Rorabaugh's

Takeover: How the Left's Quest for Social Justice Corrupted Liberalism . 710

Arie M. Dubnov: A POST-POST-ZIONIST CREDO

Review of Eyal Chowers's The Political Philosophy of Zionism:

Trading Jewish Words for an Hebraic Land. . . . . . . . . . . . . . . . . 713

Christopher Day: PERSISTENT BUT DIVERGENT FRAILTY

Review of Crawford Young's The Postcolonial State in Africa:

Fifty Years of Independence . . . . . . . . . . . . . . . . . . . . . . 717

Vladimir Rauta: WHY AND HOW THEY DID IT

Review of Feroz Hassan Khan's Eating Grass: The Making

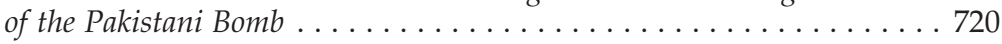

Scholarly Exchange:

America's Iraq War-on Stephen Knott's Rush

to Judgment

List of Reviewers . . . . . . . . . . . . . . . . . . . . . 727 
Subscription Information: The Review of Politics (ISSN 0034-6705) is published quarterly in February, May, August and November by Cambridge University Press, 32 Avenue of the Americas, New York, NY 10013-2473 USA/The Edinburgh Building, Shaftesbury Road, Cambridge CB2 8RU, UK for the University of Notre Dame. Annual subscription rates for Volume 75 (2013): Institutional subscription rates, print and online: US $\$ 150.00$ in the USA, Canada, and Mexico; UK $£ 87.00+$ VAT elsewhere. Institutional subscription rates, online only: US $\$ 130.00$ in the USA, Canada, and Mexico; UK $£ 75.00$ + VAT elsewhere. Institutional subscription rates, print only: US $\$ 147.00$ in the USA, Canada, and Mexico; UK $£ 85.00$ + VAT elsewhere. Individual subscription rates, print only: US $\$ 44.00$ in the USA, Canada, and Mexico; UK $£ 25.00$ + VAT elsewhere. Correspondence concerning subscriptions should be sent to: Cambridge University Press, 100 Brook Hill Drive, West Nyack, NY 10994, USA for customers in the USA, Canada, or Mexico. Customers elsewhere should contact: Cambridge University Press, The Edinburgh Building, Shaftesbury Road, Cambridge CB2 8RU, UK.

Editorial Office: All correspondence concerning submissions and manuscripts under review should be sent to The Review of Politics, University of Notre Dame, 547 Flanner Hall, Notre Dame, IN 46556. Phone: 574-631-6623. Email: ROP.Editor.1@nd.edu. Website: www.nd.edu/ rop

Abstracting and Indexing Information: Articles in The Review of Politics are indexed in the International Index to Periodicals and the Catholic Periodicals and Literature Index; abstracted in the International Political Science Abstracts; and abstracted and indexed in ABC POL. SCI., Historical Abstracts, Social Science Index (also available in the electronic versions), Book Review Index, and International Bibliography of the Social Sciences.

Copyright (C) 2013 University of Notre Dame. All rights reserved. No part of this publication may be reproduced, in any form or by any means, electronic, photocopy, or otherwise, without permission in writing from Cambridge University Press, Rights and Permissions Manager, 32 Avenue of the Americas, New York, NY 10013-2473 USA. For further information see http://us.cambridge/org/information/rights/

Periodicals postage paid in New York, NY and additional mailing offices. Postmaster: Send address changes to The Review of Politics, Cambridge University Press, 100 Brook Hill Drive, West Nyack, NY 10994-2133 USA.

Photocopying information for users in the U.S.A.: the Item-Fee Code for the publication (0034-6705/13\$9.00+.10) indicates that copying for internal or personal use beyond that permitted by Sec. 107 or 108 of the U.S. Copyright Law is authorized for users duly registered with the Copyright Clearance Center (CCC) provided that the appropriate remittance of $\$ 9.00$ per article is paid directly to CCC, 222 Rosewood Drive, Danvers, MA 01923. Specific written permission must be obtained for all other copying. 